\title{
Research on Business English Teaching Model Under MOOC Background
}

\author{
Yi Liu \\ School of Foreign Studies \\ Anhui Sanlian University \\ Hefei, China 230601
}

\begin{abstract}
The rapid development of economy and the continuous deepening of foreign exchange have put forward higher and newer requirements for the cultivation of foreign talents in our country. Based on the rapid development of network technology, screen course, as an online video course, has given a new form to business English teaching. In order to enrich the teaching mode of business English specialty, optimize the teaching effect and provide reference for the cultivation of applied talents in colleges and universities, this paper makes a research on the teaching mode of business English under the background of the course.
\end{abstract}

Keywords-MOOC background; business English; teaching model

\section{INTRODUCTION}

MOOC (massive tapping online courses) is a large-scale open network course, which is built by many famous schools in the world. It is an online classroom for the public. To meet certain requirements, we can obtain certification certificate. The emergence of MOOC causes people to think about education. The similarities and differences between MOOC and traditional classroom become the focus of research. In 2006, China's Ministry of Education explored the opening of business English major. Up to now, the number of business English majors has been increasing year by year, covering different levels and types of colleges. The construction and development of business English majors have been paid more and more attention in the field of education. However, as a new major, Business English has inevitably encountered some difficulties at the beginning of its establishment and development, one of which is the weakness of business English teachers. At present, most of the former teachers of business English in colleges and universities are teachers of traditional English language and literature. They do not have sufficient business knowledge and practical experience. The rapid development of information-based teaching mode under the background of MOOC intensifies the crisis of business English teachers' identity. It makes the deconstruction of old identity and the construction of new identity more challenging.

MOOC is a new teaching mode, representing an advanced educational and teaching concept. The foundation of its birth and development is the rise of modern information technology and network platform. The rise of
MOOC has brought fundamental changes to the educational concept of university teachers. The traditional classroom teaching mode is undergoing profound changes, but also brings severe challenges to the construction of university teachers' identity. Most business English teachers do not adapt to the rapid development of educational information process under the background of MOOC. In the process of transition from language and literature teachers to business English teachers, there is a crisis of professional identity loss and identity. The deconstruction of the old identity is not complete, the understanding of the new identity is not sufficient, and the necessary confidence in identity construction and the guidance of theory and method are lacking, which leads to the dilemma of the new identity construction.

\section{THE ANALYSIS OF MOOC' S LEARNING MODE}

\section{A. Characteristics of MOOC}

- As the name implies, "M" stands for Massive, which is different from traditional courses with only a few dozen or hundreds of students. A MOOC course can be used by tens of thousands of people, up to a maximum of 160000 . The second letter "o" stands for an open, interest-oriented course. Anyone who wants to learn can come in to learn, regardless of nationality, only need a mailbox, can register to participate; the third letter "O" stands for Oinllle (online, learning on the Internet, break the space-time limit; The fourth letter " $\mathrm{C}$ " stands for course. At the same time, MOOC also has a wide audience, strong selectivity, freedom, and so on. Anyone, no matter what class they belong to, or what they study, The MOOC itself is rich in content and highly selective, and the courses do not need to go to local schools for classroom study in person. By simply logging in to the computer, you can easily learn online, break the space-time limit, and you can schedule your learning according to your time. This is the embodiment of MOOC freedom. [1] Deep human analysis also has the characteristics of saving and reusing. Teachers only need to complete one video teaching, and their teaching resources can be reused. In this way, labor and resources can be greatly saved to a certain extent, so it has the characteristics of saving. 
- Development of Business English course at home and abroad. In the 1990s, the development of business English teaching in China became more and more prosperous. In order to develop business communication skills, business English courses focus on teaching students business skills in negotiation, meetings and oral presentations. However, there are still many problems in business English courses in China. Many universities offer business English courses without considering their own discipline characteristics. They just add courses such as international business, macroeconomics, etc., and arrange business English courses in the last semester. This time period is also close to graduation, everywhere looking for a job, resulting in teaching effectiveness greatly reduced.

- The research on the development of the course at home and abroad. Mooc was first proposed by George Siemens and Stephen Downes in 2008. Then spread widely in the United States, where in 2011 Sebastian Thrunn, a professor at Stanford University, and his colleagues offered a free introduction to artificial Intelligence to Artificial Intelligence). Online courses, as many as 160000 people registered, and the development of the curriculum to the climax. Anyone who has a network connection can enter a course, acquire course resources, and exchange lessons with other students.

MOOC is called a large-scale Open online course. Professor Li Xiaoming, head of the working group of Peking University's MOOC, defined the class as "one that is responsible by the keynote teacher, who supports the participation of a large number of people through the Internet, with video lectures, homework exercises, forum activities, and circulars."

- The teaching process in which elements such as tests and exams are intertwined. The rise of Mudu course depends on people's pursuit of fair and democratic education and modern mature information technology. With the emphasis of "interaction and feedback" and the "online learning community", the following characteristics are distinguished from the rapid rise of traditional classes and other online courses. Online: students have more autonomy to learn than traditional classrooms. Students can learn online flexibly to suit their own time and rhythm. At the same time, with big data analysis as a reference, learners can refer to the learning behavior and learning process recorded in the background, and adjusts the learning situation according to the timely evaluation of learning effect. Openness: compared with the traditional video open course, the core change of the course lies in the completion of the opening from static learning resources to the opening of the learning process. The course is no longer the opening of a single teaching resource, but the opening of the process of interaction, participation, teaching implementation and evaluation. It really realized the change from the teaching content as the center to the learner-learning-centered open curriculum. At the same time, through online education, $\mathrm{Mu}$ class reduces the cost of providing quality education, and realizes that anyone can study the courses of famous schools and teachers anywhere for free. 3. Timeliness and Diversity of Evaluation: relative to traditional classroom Evaluation Methods, the evaluation of learning more attention to process, diversity, diversity evaluation.

\section{B. Advantages and Disadvantages of MOOC}

Compared with the traditional classroom, the students can choose the superior teaching resources in the first-class university to study. The teaching method of the quality of MOOC is the combination of teaching video and answering multiple choice questions. That is, knowledge learning has changed from "teaching-led learning" to "seminar and promotion learning". Through a relatively complete teaching model, such as participation, feedback, homework, discussion, evaluation, examination and certification, etc., It ignites the enthusiasm of the learners to participate in the course study, thus consummates the process learning way, enables the learner to grasp the knowledge and the ability truly, enhances the learner's learning enthusiasm. However, compared with the traditional classroom, MOOC has delay in the interaction between teachers and students. Unlike the traditional classroom teaching, the teacher can pay attention to the students' reaction at any time, so as to communicate and adjust the response time of the course effect of .MOOC. It is very difficult to remedy the published course video even if it is fed back to the teacher through the forum exchange. Therefore, compared with the traditional classroom MOOC course, the interaction of MOOC course has some difficulties, and the interaction between the students is delayed. Is an important link in the teaching of MOOC platform learning, learners lack of classroom teachers and students, students and students between the communication and discussion links, even if there is a forum exchange, But they are not as real and timely as the natural profound. MOOC requirements for students than people to learn a large number of high, need to have a strong self-control, self-adjustment and adaptation to the ability to learn.

The diversified development of English majors, the strong demand for business English talents in the 21st century, the integration of trade and information modernization technology promote the integration and development of interdisciplinary, traditional English majors are in a period of transition. Develop in the direction of diversification. ESP has a strong momentum, the level of diversification, the direction of refinement and other salient features. Business English is a kind of special purpose English, which is different from the traditional English major. It has a unique academic foundation and emphasizes its application and compounding. The curriculum and other aspects have different characteristics from the general English. At present, the demand for foreign economic and trade personnel in the national economic development and higher education transformation is increasingly strong. The new social demand of the compound talents with both English professional knowledge and business skills is increasingly welcomed by the employing units under the 
background of the era of MOOC, which puts forward new requirements for the cultivation of business English majors in colleges and universities. Business English teachers should enhance their subjective initiative, take an active part in teaching reform, adapt to the background of the diversified development of English majors and educational informatization, improve their own business awareness and business literacy, and actively carry out the old ones. The deconstruction of identity and the construction of new identity.

Compared with the traditional teaching courses, the learners are more active and more cheerful in the learning atmosphere of MOOC. Video and picture interspersed, more image and more interesting. Students' interest is improved, their mentality is positive, and their mastery of learning is more favorable. Compared with the traditional classroom, MOOC is more free and open. Students can learn according to their own interests and needs, which is conducive to cultivating positive emotions. It is more favorable for students to receive knowledge. For the courses learned on the MOOC platform, the impact on students is enormous. The satisfaction gained from MOOC has a certain auxiliary effect on students' classroom learning, students are more positive and confident, better auxiliary classroom learning, To improve the enthusiasm of learning. The rise of MOOC is conducive to the openness and extensiveness of learning. MOOC comes from famous schools all over the world. It is rich in content and abundant in resources, which basically meets the needs of learners and solves the problem of the limitation of traditional classroom subjects. With the MOOC platform, anyone who wants to learn has the opportunity to accept resources. Learners from all over the world can study quality courses free of charge as long as they surf the Internet. The development of these curriculum resources for everyone, no matter where you are, what your career, what your identity, has greatly improved the reach and breadth of education. At the same time, MOOC learning makes them more flexible to arrange their spare time, which is of great significance to students' time management ability. Learners can use computers to complete their studies around the world. Learning can be arranged in one's scattered time, and the maximum efficiency can be used to charge oneself. As a new form, the influence of MOOC on students cannot be denied. At the same time, MOOC requires students' willpower and patience. Students need to have a good foundation and learning motivation, in order to persist in learning the whole course, and without the supervision of teachers, students' self-control requirements are very high. As a kind of traditional teaching method, the traditional classroom has played an irreplaceable role.

\section{RESEARCH ON BUSINESS ENGLISH TEACHING MODEL UNDER MOOC BACKGROUND}

It embeds the teaching idea of "Mu" course to realize the mutual benefit of teaching. Since the use of "curtain lesson", it has been favored by teachers and students alike, and the reason why it can get such a high evaluation is that the teaching idea of curtain course has the characteristics of development and sharing, and the reason is that the teaching concept of curtain course has the characteristics of development and sharing. With the characteristics of interactivity, ${ }^{[2]}$ the best way to implement the studentcentered teaching form is to make the students feel that they are the masters of knowledge learning, so that the process of business English teaching has changed from "want me to learn" to "I want to learn". The former one-way teaching mode is transformed into an interactive teaching model. For example, in learning 20 common sentence patterns at the end of business English correspondence and telegram, teachers can interact with their students in curtain teaching. If students put forward a sentence pattern, the teacher should also put forward a sentence pattern. Some students propose "we should be grateful for your trial order" and the teacher should also propose a sentence pattern, such as "we assure you of our best services at all times". And it constructs a regular teaching mode of cooperation and interaction between teachers and students. Under the concept of teaching, not only students' English learning ability will be further improved, but also teachers will make progress, which is a process of teaching with each other. As soon as curtain teaching is carried out, it becomes popular all over the world, which is inseparable from the individualized features of screen teaching: screen teaching is not limited to time and place, and it can be viewed from time to place, anytime and anywhere. This essentially breaks down the limitations of traditional classroom teaching.

The course of business English translation is based on the combination of basic English teaching and ESP teaching, and is based on content, in order to cultivate the translation of business field, translation talent for the purpose of advanced stage of foreign language teaching. The teaching content of business English translation involves English-Chinese language comparison, cultural comparison, lexical, sentence and discourse translation strategies, as well as business genre-based translation strategies and techniques. At present, business English translation teaching is mostly stuck in the traditional teaching mode, the teaching form is mostly single classroom teaching, the content is obscure and boring, the task is heavy, the classroom activity design is single, the student passively accepts in the classroom does not have time to think. Problems encountered after class cannot be solved in time, teaching quality is not satisfactory. In addition, the teacher's teaching design is limited to the teaching of knowledge content, but neglects the most important comprehensive application and practice in the category of business English, and the teaching effect is poor, deviating from the original curriculum setting goal and failing to realize the training scheme.

The design of business English translation course under mixed teaching mode can be divided into three parts: before, during and after class. The three links echo each other and build up the basic framework which is different from the traditional classroom. Prophase analysis and design. Before entering the classroom, teachers should plan the teaching objectives, teaching contents, students' characteristics and teaching environment of business English translation courses. At the same time, referring to the syllabus, the teaching objectives and concrete contents are decomposed and planned, the knowledge points are subdivided, and the 
relationship between each other, the level and the extension is found out. According to the teaching target of subdivision, the content suitable for self-study before class is selected, and the contents that need to be taught in class and those that need to be reviewed and expanded under the class are selected, the course flow is decomposed reasonably, and the connection mode of each link is reasonably arranged. The organization and activity design of classroom knowledge points. The soul of the flipped classroom based on the Moo lesson is that the knowledge content has been imparted through the Moo system before the class. The important content in class is the internalization of knowledge. Therefore, the design of organization and classroom activities of face-to-face knowledge points is the core link of mixed teaching mode. The practical features of the business English translation course require that the design of knowledge points in the mixed classroom should be applied to the combination of horizontal and vertical models. In horizontal organization, the course should break the limitation of translation tool, expand the business link and business knowledge background of business English generation, and combine business case to make students have a more perceptual understanding of business English translation. In vertical organization, teachers can conduct genre-based business case translation exercises, design group activities or discussion activities, explain and analyze specific business translation skills, requirements and strategies after the introduction and decomposition of knowledge points. In order to inspire students to think, cultivate students independent, dialectical thinking.

In the new teaching mode of digitization, information and modernization, the teachers' working mode, basic function, ability quality and teacher-student relationship have all changed different from the past. Business English teachers are facing an unprecedented challenge. How to abandon the traditional teaching methods and realize the teaching style of keeping pace with the times while updating the knowledge has become an urgent task. At the same time, the status and role of teachers have changed greatly in the new educational model of MOOC, and the transformation of the status of business English teachers has become an urgent and urgent problem to be solved. Business English teachers should not only expand their business knowledge, improve their business literacy and cross-cultural business communication ability, but also realize the necessity and importance of changing their identity. We should improve our understanding of identity transformation in the new era, overcome all kinds of psychological obstacles in the process of identity transformation, and actively deconstruct old identity and construct new identity.

The background of the information age of MOOC gives business English teachers a new type of professional identity which is different from that of general English teachers. As a new social group in the field of education in China, business English teachers should have the knowledge structure, language ability and basic skills of traditional English language and literature teachers who must also have professional business knowledge and cross-cultural business practice and communication skills. Therefore, under the guidance of identity theory and teacher identity theory, business English teachers should not only listen, speak, read, write, translate and other basic English language skills, but also from the business professional knowledge, business practice ability, etc. This paper explores the construction of new identity in cross-cultural business communication ability, deconstructs the old identity in specific teaching activities and business practice, and constructs the diversified new identity of business English teachers.

\section{THE POSITIVE EFFECT OF MOOC ON BUSINESS ENGLISH CURRICULUM DESIGN}

Mooc on business English syllabus design. The specified business English syllabus firstly according to the specific business skills requirements, such as meeting skills, presentation skills, social skills, writing skills and so on. The $\mathrm{Mu}$ class syllabus and the traditional syllabus are somewhat different. The traditional business English teaching syllabus is mainly by teachers' use the outline of the content is mainly related to teaching. However, based on the business English teaching syllabus $\mathrm{Mu}$ class is mainly learners, and syllabus coverage than traditional syllabus to extensive, $\mathrm{Mu}$ class syllabus basically includes: course introduction, curriculum objectives, curriculum materials, and activities job evaluation methods (mainly for learners) and curriculum recommendations. A systematic and complete teaching syllabus can make learners at the beginning of the course have a clear understanding. The choice of teaching methods after class. Business English Mooc course design provides a lot of information and materials, which helps learners to learn independently. Different scholars have different definitions of "task" in task-based learning method. But these definitions all include: goals, knowledge input, ${ }^{[3]}$ classroom activities, teacher guidance, students' learning and learning background. It can ensure that the language requirements of the learners are in line with the current level, and that the task selection meets the learner's ability requirements. Taskbased learning methods emphasize the input of the language, and the learning scene is as close as possible to the real scene. Task setting has a clear goal. Problem-solving learning methods are similar to task-based learning methods and are based on cognitive learning theory. One of the features of business English is cultural differences, so you can connect one culture with another via the Internet. It helps us to better understand foreign culture.

In the 21 st century, economic globalization, trade integration and information modernization technology promote the integration and development of interdisciplinary. Traditional English majors are in a period of transition and developing towards the direction of diversification. ESP has a strong momentum, the level of diversification, the direction of refinement and other salient features. Business English is a kind of special purpose English, which is different from the traditional English major. It has a unique academic foundation and emphasizes its application and compounding. The curriculum and other aspects have different characteristics from the general English. At present, the demand for foreign economic and trade personnel in the national economic development and higher education transformation is increasingly strong. The new social 
demand of the compound talents with both English professional knowledge and business skills is increasingly welcomed by the employing units under the background of the era of MOOC, which puts forward new requirements for the cultivation of business English majors in colleges and universities. Business English teachers should enhance their subjective initiative, actively participate in teaching reform, adapt to the background of the diversified development of English majors and education informatization, and improve their own business awareness and business literacy. The deconstruction of the old identity and the construction of the new identity are actively carried out.

Education is the first attribute of business English teachers, and educator is the primary identity of business English teachers. The meaning of educators is threedimensional and multidimensional, such as the design and organizer of classroom teaching, the promotion and guidance of students' physical and mental development, etc. Under the background of MOOC, the identity of business English teachers as educators is endowed with a new connotation of the times. In MOOC teaching, teachers teach only a small part of the classroom teaching, and most of the teaching time is allocated to the interactive communication between teachers and students through the network. Teachers teach the teaching content by making micro video, and then participate in and guide the interactive discussion between students through virtual interactive technology. Under the new education mode of MOOC, students are the center of learning, they take part in the construction of knowledge actively, the characteristics of students' individualized learning are obvious, and the teaching method has carried on the brand-new operation, therefore, Teachers should make timely and dynamic adjustments according to the needs of students. To solve the problems and doubts encountered by students in the course of learning MOOC courses. The teaching methods in the context of MOOCs are completely different from the teacher-centered teaching methods in the traditional teaching mode. It gives new educational features to business English teachers. More emphasis is placed on teachers' spirit of teamwork (for example, curriculum design teams should adjust curriculum teaching timely according to students' feedback on curriculum, etc., teachers are no longer traditional knowledge imparting and authoritative, etc.) The only controller and ruler of the classroom are the manager of classroom teaching and the guide of knowledge dissemination.

Strengthen the development of resources, improve the ability of self-study. ${ }^{[5]}$ From the theoretical analysis of screen teaching, we can know that screen teaching has a strong openness, and return the class to students as much as possible, which will help students to improve their autonomous ability, if they want to better play the value of screen teaching. Therefore, it is necessary to speed up the development of curricular resources and to integrate teaching resources in a modular manner, which is also an important and difficult point in the teaching of curtain classes. For this reason, the author thinks that teachers can proceed from the demand of market talents in the course of developing curriculum resources. For example, in the teaching of business English in higher vocational education, students should master certain knowledge of English, we should also have certain knowledge of economics and some practical English in the course of business negotiation. In order to do this, we can divide the students' professional ability into modules. Making 10 or 15 minutes teaching video for students, allowing students to prepare their own lessons through video, and making cooperative exploration through screen platform, so that students can know the contents of the teaching in advance and improve the efficiency of classroom teaching. Teachers can also make use of the curricular platform, through the development of relevant curriculum resources and students to carry out simulation training, so that students can quickly integrate into the business negotiation environment, so as to achieve the improvement of English skills.

Infuse the teaching method of MOOC to enhance the teaching effect. As soon as the curtain teaching is carried out, it becomes popular all over the world, which is inseparable from the individualized features of screen teaching: screen teaching is not limited to time and place, and it can be viewed by video at anytime and anywhere. This essentially breaks the limits of traditional classroom teaching. For example, in the teaching of English discourses, the traditional teaching mode is that teachers analyze the words and meanings in the text first, and then lead the students to explain the English sentences. [6]Audio and other modes Students' interest in learning and then discourse learning enhances the appeal of text teaching and thus deepens the teaching effect. In grammar teaching, the traditional teaching is mainly based on the teaching of grammar knowledge, and the classroom is boring, but the curtain teaching can proceed from the knowledge network and combine with the actual language communication to teach grammar knowledge, and also through the website. Expand the knowledge of grammar in order to achieve the improvement of teaching effect.

\section{CONCLUSION}

The teaching mode of screen course breaks the limitation of teaching time and space, and promotes students' autonomous learning ability. Therefore, in the future business English teaching, we should expand the application field and mode of screen teaching. In order to improve students' English knowledge and oral communication ability, ${ }^{[4]}$ students' English learning level can be greatly improved. The mixed teaching mode of the combination of "admiration" and "flip" not only subverts the traditional teaching ideas and methods of business English translation teaching, but also urges teachers to reflect on the shortcomings of the old teaching methods. The emergence of the classroom of admiration and turnover deconstructs the teacher-centered passive teaching and infusion classroom, constructs the network platform, the interaction between students and teaching resources, and changes the traditional role of teachers and students. It realizes the teaching transformation from content-centered and teacher-centered curriculum to learning-centered and student-centered teaching. This multi-interactive mode is an important way to promote business English teaching, and also provides a way to deepen the reform of business English teaching. 


\section{ACKNOWLEDGEMENT}

This paper is the stage research results of Large-scale online open course (MOOC) demonstration project--English Correspondence on Foreign Trade, Item Number: (2016MOOC152) and Large-scale online open course (MOOC) demonstration project--Business English Negotiation, Item Number: (2016zlgc020) and Large-scale online open course (MOOC) demonstration project-Business English Negotiation, Item Number: (2017mooc132) .

\section{REFERENCES}

[1] Zhang Wen-yuan. Effect of the development of Moocs on higher education in China and its countermeasures [J] .Journal of Hebei normal University (Education Science Edition: 2014).

[2] Liu Haizhou, Li Tao An. Study on the Teaching Mode of College English flipping Class based on Move course [J] .Examination Weekly (in Chinese).

[3] Chen Jinlin. The study of admiration and Foreign language Teaching in big data's time: challenges and opportunities $[\mathrm{J}]$.Foreign language Audio-Visual Teaching in 2015.

[4] Zhang Qian-rong. Problems in Business English Translation course and improvement measures [J] .Journal of Hubei correspondence University.

[5] Lu Lixiang. Probe into the Reform of English Teaching in higher Vocational Education under the background of Moulding course [J]. Overseas English, 2016.

[6] Yan Li. A study on the prospects and Countermeasures of English Teaching in higher Vocational Colleges under the background of Moulding courses [J]. Education in Asia and the Pacific.2016.11. 